\title{
The Differences of Nurses' Work Stress in The Intensive Care Unit and Inpatient Room in A Psychiatric Hospital
}

\author{
Irman Somantri, Taty Hernawaty, Ratna Multisari \\ Faculty of Nursing, Universitas Padjdadjaran \\ Email: ratnamultisari.25@gmail.com
}

\begin{abstract}
Inpatient room in a psychiatric hospital is divided into the acute (intensive) room and non-acute (inpatient) room. Several types of research showed different levels of work stress experienced by nurses in those rooms. The work stress is a form of individual response towards physical and psychological demand caused by the interaction of an individual to the working environment. This research aimed to know the difference in the work stress levels of nurses in psychiatric intensive care unit and inpatient room at a Psychiatric Hospital in West Java Province. This research used a comparative analytical design. The 104 samples were chosen through proportional random sampling technique. The data were collected through New Brief Job Stress Questionnaire (New BJSQ) instrument containing 29 items. The technique of data analysis used was the Mann-Whitney test. The results showed that job stress levels of nurses in psychiatric intensive care unit and inpatient room were low with the median score 42 $(\mathrm{SD}=7.706$ for the intensive care unit and in the inpatient room was $38(\mathrm{SD}=6.167)$. The results of the Mann-Whitney test found $p$-value $(0.047)<0, .5$. In conclusion, there is a bit different in the job stress level of nurses in psychiatric intensive care unit and inpatient room. Maintaining the mechanism of adaptive coping, adding the number of nurses, and the policy regarding nurse room rotation schedules would be solutions to overcome with work stress.
\end{abstract}

Keywords: Inpatient room, Intensive Care Unit, nurses, work stress. 
Irman Somantri: The Differences of Nurses Work Stress in The Intensive Care Unit

\section{Introduction}

Stress would happen to anyone and anywhere (Gaol, 2016). Stress is a person's cognitive assessment of one's physical, psychological and social state (Appley \& Trumbull, 1967; Lazarus \& Folkman, 1987 in Ebstein, 2015). Factors that cause stress are divided into two, including internal factors (personality, abilities and cultural values) and external factors (work and outside of work (Sunyoto \& Burhanudin, 2011).

Stressthat caused by someone's work is called work stress. According to NIOSH (1999 in Friis, 2012), work stress is the demand for work that is not in accordance with the capabilities, resources, and needs of workers, resulting in physical and psychological responses deviating from normal functions. The most stressful work according to the National Safety Council (2004 in Sitorus \& Wulandari, 2015) is nurses.

Mental health nurses are most exposed to stress in nursing practice (Yoshizawa, et al., 2014). Nurses who work in Psychiatric hospitals according to the study of Abdullah and Abbas (2015) found male and female nurses would experience work stress. A study explained that nurses working in Psychiatric hospitals experience moderate levels of work stress (Hasan, 2017), and inpatient rooms for mental patients are the rooms that have the highest level of work stress on nurses compared to other rooms (Konzon \& Zacharova, 2016; Totman, Hundt, Wearn, Paul, \& Johnson, 2011). Another study conducted in the inpatient unit of the Regional Psychiatric hospital of North Sumatra Province explained that nurses working in inpatient units experienced work stress (Ulfah, 2011).

Research related to work stress in the acute room or PICU has been done, the results found that nurses had experienced moderate to high work stress (Dawood, Mitsu, \& Monica, 2017). Another study conducted by Setiawan (2015) in the Surakarta Hospital Hospital PICU stated that $30 \%$ of nurses experienced severe work stress and $20 \%$ of nurses experienced panic category of work stress. The occurrence of work stress on nurses according to Zaki (2016) due to the condition of patients, nurses in the PICU room should treat patients with acute mental disorders that have characteristics include violent behavior, unmanageable and have a desire to commit suicide. According to Currid's (2008) research that the stress of nurses working in the PICU room was caused by the workload. The excessive workload on nurses is due to the lack of nurse resources. The number of nurses working in the room is less then the task that must be done by a nurse would be too much.

Nurses who work in quiet or sub-acute care rooms where nurses working in quiet care rooms also experience moderate to high work stress (Febriani, 2017). Asril's research (2010) states that nurses experience moderate work stress $(69.8 \%)$ and work stress in the high category $(24.09 \%)$. Job stress that occurs in nurses who works in the care room is caused by the patient's condition (Widioretno, 2018). Even though the patient is in a quiet room or in a maintenance category but sometimes the patient suddenly mad. If the nurse is not ready for these conditions it would cause work stress for nurses. According to research conducted by Sari, Yusran and Ardiansyah (2017) work stress that occurs in nurses in quiet care rooms may also be caused by the excessive workload. The excessive workload on nurses in quiet inpatient rooms is caused by nurses should observe and monitor patients' behavior strictly.

Nurses who experience work stress would feel tired, run out of energy, dizziness, indigestion, anxiety, insomnia, shortness of breath and irritability (Wijono, 2010). The impact of work stress includes decreasing concentration, making inappropriate decisions, and not optimal in implementing nursing care (Moustaka \& Constantinidis, 2010). Job stress that occurs in nurses may cause poor nurse performance. The research conducted by Arbabisarjou, Ajdari, and Omeidi (2013) stated that there is a relationship between work stress and nurse performance when stress occurs the nurse's performance would decrease. The impact of nurse work stress also influences the competitiveness of hospitals with others, jeopardizes the continuity of hospital organizations, and decreasing the quality of services (WHO, 2003 in Yana, 2015).

The Psychiatric hospital of West Java 
Province (RSJ) is a Type A Psychiatric hospital managed by the West Java Provincial Government and a referral hospital in West Java Province. Services provided by the West Java Provincial General Hospital include outpatient care, hospitalization, emergency room, and rehabilitation. The inpatient room of the West Java Provincial General Hospital is divided into two rooms, the Intensive Care Room and the Quiet Inpatient Room.

The results of interviews conducted in the Quiet Inpatient Room stated that 4 out of 5 nurses feel easily emotional, feel anxious and feel less satisfied in caring of patients. Interviews were also conducted on nurses working in the Intensive care Room, where 4 nurses who conducted interviews said that when treating patients, they feel emotional, feel anxious and feel less satisfied with the work that has been done. Even one of the nurses said he felt unmotivated to come to work and felt tired when working. In addition, based on information from several nurses working in Intensive Care Rooms and Quiet Inpatient Rooms, they often arrive late to work and want to resign from the Psychiatric hospital and move to a public hospital. The research related to the different stress levels of nurses working in Intensive Care Rooms and the Quiet Inpatient Room of the West Java Provincial Hospital had never been done. Therefore, researchers are interested in conducting research related to these issues.

\section{Method}

The design of this study used comparative analytical research methods. The variables in this study were the work stress of nurses in the Intensive Care Room and the stress of nurses working in the Quiet Inpatient Room. The population in this study were nurses who worked in the Intensive Care Room and the Inpatient Room, which are 140 nurses. The samples were chosen using proportional random sampling techniques. The samples were 48 nurses from the Intensive Care Room and 56 nurses from the Quiet Inpatient
Room. The instrument in this study was the New Brief Job Stress Questionnaire (New BJSQ). New BJSQ is a special questionnaire for measuring work stress with 29 statements. The validity and reliability of New BJSQ instruments were 0.80 and 0.70 (Inoue et al., 2014 in Shimazu, Nordin, Dollard \& Oakman, 2016). Back translate questionnaire is done so the language in the questionnaire can be understood by the respondents. The content validity was carried out to the expert lecturer in management nursing at the Nursing Faculty of Padjadjaran University. The results of the content validity test stated the content of the instrument was appropriate for the study. The researcher also conducted face validity to 5 nurses who had the same characteristics as the respondents. The results of the face validity stated that the statements in the questionnaire are understandable and easy to understand.

This research was conducted in the Intensive Care Room and Quiet Inpatient Room at the Psychiatric Hospital of West Java Province. The study was conducted from January to June 2018. Univariate analysis was used to determine the stress level of nurses' work in the Intensive Care Room and the Quiet Inpatient Room. The results analyzed and interpreted based on the mean. The standard of mean in the New BJSQ questionnaire is 72.5 , the lowest score is 29 and the highest score is 116 . Nurse work stress is interpreted as high stress if the median is low or the median value of the respondents is $<$ mean standard. Bivariate analysis was used to determine the difference in stress levels of nurses' work in the Intensive Care Room and Quiet Inpatient Room. Before conducting a different test the normality test is carried out first with the results of the p-value of Intensive Care Room and Quiet Inpatient Room which are 0,000 and 0,021 so that the two data are not normally distributed. Therefore, to do a different test, the researchers used the MannWhitney test

\section{Results}

Table 1. Work stress of nurses in a Psychiatric Hospital

\begin{tabular}{|c|c|c|c|c|c|c|}
\hline Room & Mean & Median & $\begin{array}{c}\text { Standard of } \\
\text { deviation }\end{array}$ & Min & Max & P Value \\
\hline The Intensive room & 42.25 & 42 & 7.706 & 31 & 74 & 0.047 \\
\hline The quite room & 38.93 & 38 & 6.167 & 29 & 52 & \\
\hline
\end{tabular}


Irman Somantri: The Differences of Nurses Work Stress in The Intensive Care Unit

Based on table 1, it is known that the median in Intensive Care Room and Quiet Inpatient Room both have values below the standard mean, which are $42<72.5$ and 38 $<72.5$. It can be interpreted that the work stress in the Intensive Mental Room and Quiet Inpatient Room were low. According to the median value, the work stress of the Intensive Care Room has a higher median value compared to the Quiet Inpatient Room. It can also be seen that the result of the p-value of the Mann-Whitney test was 0.047, there is a significant difference between work stress in the Intensive Care Room and in the Inpatient Room Quiet with p-value is $<0.05$

\section{Discussion}

According to bivariate analysis, it was found that there were differences between the work stress of nurses in the Intensive Care Room and the Inpatient Room ( $p$-value $=0.047$ ), the higher work stress was experienced by nurses in the Intensive Care Room. It is because of the differences in patients' conditions. Intensive Care Rooms or often called Psychiatric Intensive Care Units (PICU) according to the National Association of Psychiatric Intensive Care and Low Secure Units (NAPICU) are rooms for patients in the phase of acute psychiatric disorder and they could not control themselves (NAPICU, 2014). Patients with acute mental disorders usually have aggressive behavior (Iversen, Aasen, Guzey, \& Helvik, 2016). Several studies have found that aggressive behavior in patients causes work stress to nurses (Konstantinos \& Christina, 2008; Aji \& Ambariani, 2014). Therefore, usually, nurses who work in intensive or acute rooms have higher job stress than nurses who work in quiet rooms. This is because of patients' conditions, in the quiet room, the patients are in the maintenance category and they are able to interact with other people.

In addition, besides the patient's conditions, the work stress experienced by nurses in each unit was varied (Chiang \& Chang, 2012). This is because of the workload of each room is different. Senining and Gilchrist (2012) stated that stressors for nurses who work in the PICU room were the workload of nurses.
One of the causes of excessive workload is the lacking number of nurses, it impacts nurses' tasks become too much (Sobekwa \& Arunachallam, 2015). In the West Java Provincial General Hospital, the number of nurses in the Intensive Care Room was less than nurses in the Quiet Inpatient Room.

When researchers collected data in the Intensive Care Room, they found nurses who in duty was not in accordance with the work schedule. Interviews of 4 nurses in the Intensive Care Room revealed that sometimes they had to work 24 hours or 3 shifts directly (afternoon shift, night shift, and morning shift). According to Tayyari and Smith (1997 in Satrio, 2015), the duration of work shifts is not more than 8 hours. When someone works over a predetermined time then it can cause work stress on that person (Sato, Miyake, \& Theriault, 2009). The work stress experienced by Intensive Care nurses is higher than the Quiet Inpatient Room.

The results of this study stated that there were differences in the level of work stress in the Intensive Care Room and Quiet Inpatient Room, but the overall data analysis showed nurses in both units have low work stress. The results of this study are in line with the research carried out previously which found that nurses working in the Intensive Care Room had low work stress (Ratnaningrum \& Putri, 2012). Other studies have found nurses who work in quiet inpatients have low levels of work stress (Muatsiroh \& Siswati, 2017

Everyone has a different coping mechanism when dealing with stressors. Adaptive coping would produce good adaptation behavior so that a person is protected from stress and vice versa if someone has maladaptive coping then adapts poorly so that the chance of stress becomes higher. Mulyani's research, M and Ulfah (2017) concluded that coping mechanisms related to work stress, nurses with adaptive coping mechanisms had low levels of work stress. Therefore, the researchers argue that nurses in Intensive Care Rooms and Quiet Inpatient Rooms experience low levels of work stress because they may have adaptive coping mechanisms.

The result of an adaptive coping mechanism is a good adaptation, as well as nurses who work at a Psychiatric hospital. This is consistent with the results of the study 
by Utomo and Sulastri (2009) found that there was a relationship between nurses' work stress and nurse adaptation, low work stress was influenced by good nurse adaptation. Other research also states that there is a relationship between adaptation and work stress (Asmarani, 2017).

In relation to coping and adaptation, the low work stress of nurses in the Intensive Care Room and Quiet Inpatient Room may be due to good communication between employees. Good communication reduces the occurrence of misperceptions and conflicts between colleagues. Lack of communication between nurses and doctors often occurs and ultimately causes stress to nursing (Akel \& Elazeem, 2015). This is in line with Rahmawati and Purnawati's (2008) research found that communication between nurses and doctors is related to the occurrence of work stress on nurses. Therefore, researchers argue that the low stress of work in the care unit of the research settings might be due to the communication of nurses and doctors are well established.

Nurses also communicate with coworkers and supervisors. Poor communication with coworkers and supervisors causes conflict. Conflicts that occur in a person result in uncomfortable and depressed feelings. Previous research found the cause of nurses experiencing work stress was a conflict with work colleagues or supervisors (AbuRuz, 2014; Mohamedkheir, Amara, Balla, \& Mohamed, 2016). According to researchers, the low work stress that occurs in Intensive Care Rooms and Quiet Inpatient Rooms is that there is no conflict with work colleagues or supervisors.

Communication with coworkers and supervisors also influences the support provided. Support obtained from the workplace is a positive influence, creating a sense of comfort and calm so when working it does not feel burdened, and productive. In addition, co-workers who support each other create situations of mutual assistance and cooperation. In addition, to supporting from co-workers, support from supervisors would also have an impact on one's performance. The research conducted by Ayomi (2016) explains the lack of support from the work environment is a stressor that increases work stress on nurses and vice versa. Based on the elaboration, the researcher concluded that the cause of the low stress of nurses' work in this study was the support of good colleagues and supervisors.

\section{Conclusion}

This study aims to determine the differences in stress levels of nurses in Intensive Care Rooms and Quiet Inpatient Rooms at Psychiatric Hospital, West Java Province, the results of this study indicate differences in the level of stress on nurses' work. Based on the median value, it was concluded that the nurse's work stress level was higher in the Intensive Care Room compared to the Inpatient Room. However, from the results of the overall interpretation, it was stated that the level of work stress in the Intensive Care Room and Quiet Inpatient Room both had low nurse work stress. Based on the results of the study the researchers suggested that nurses should maintain an adaptive coping mechanism and good communication between employees. Meanwhile, the hospital can arrange the placement of nurses in each room and increase the number of nurses.

\section{References}

Abdullah, M. A., \& Abbas, I. A. (2015). Assessment of Job Stress for Nurses in the Psychiatric Hospital at Baghdad City. Kufa Journal For Nursing Science, 5(1).

AbuRuz, M. E. (2014). A Comparative Study about the Impact of Stress on Job Satisfaction Between Jordanian and Saudi Nurses. European Scientific Journal, 10(17).

Aji, A. B., \& Ambariani, T. K. (2014). Coping Stres Perawat dalam Menghadapi Agresi Pasien di Rumah Sakit Jiwa Dr. Radjiman Wediodiningrat Lawang. Jurnal Psikologi Industri dan Organisasi, 3(1).

Akel, D. T., \& Elazeem, H. A. (2015). Nurses and Physicians Point of View Regarding Causes of Conflict between them and Resolution Strategies Used. Clinical Nursing 
Irman Somantri: The Differences of Nurses Work Stress in The Intensive Care Unit

Studies, 3(4), doi:10.5430/cns.v3n4p112.

Arbabisarjou, A., Ajdari, Z., \& Omeidi, K. (2013). The Relationship between Job Stress and Performance Among the Hospital Nurse. Word of Science Journal, 2, doi: 10.13140/2.1.1992.7045.

Asmarani, R. (2017). Hubungan Antara Kemampuan Adaptasi terhadap Kebisingan dengan Stres Kerja Karyawan. Jurnal Studia Insania, 5(1). Doi: 10.18592/jsi.v5i1.1356.

Asril. (2010). Hubungan antara Beban Kerja dengan Stres Kerja pada Perawat Rumah Sakit Jiwa Tampan Pekanbaru. Skripsi: Universitas Islam Negri Sultan Starif Kasim Riau.

Ayomi, M. B. (2016). Factors Affecting Nurses' Workplace Stress Inyowari Hospital of Sentani District, Jayapura. KnE Social Science, 183-191, Doi:10.18502/kss. v1i1.451.

Chiang, Y., \& Chang, Y. (2012). Stress, Depression and Intention to Leave among Nurses in Different Medical Units: Implication for Healthcare Management/Nursing Practice. Health Policy, 108(2-3): 149-157, Doi: 10.1016/j.healthpol.2012.08.027.

Currid, T. J. (2008). Experience of Stress among Nurses in Acute Mental Health Settings. Nursing Standard, 23(44): 40-46. Doi: $10.7748 /$ ns.23.44.40.s51.

Dawood, E., Mitsu, R., \& Monica, A. (2017). Perceived Psychiatric Nurses Job Stress: A Cross Sectional Study. IOSR Journal of Nursing and Health Science, 6(2), 37-47, doi: 10.9790/1959-0602063747.

Ebstein, A. M. (2015). The Relationship Among Coping, Occupational Stress, and Emotional Intelligence Newly Hired Nurses in an Oncology Setting. Dissertation: The State University of New Jersey.

Febriani, S. (2017). Gambaran Stres Kerja pada Perawat di Ruang Rawat Inap Bagian Perawatan Jiwa Rumah Sakit Khusus Daerah Provinsi Sulawesi Selatan Tahun 2017.
Skripsi: Universitas Islam Negri Alauddin Makasar.

Friis, R. H. (2012). Occupational Health and Safety for the 21st Century. Amerika: Jones $\&$ Bartlett Learning.

Gaol, N. T. (2016). Teori Stres: Stimulus, Respon, dan Transaksional. Buletin Psikologi, 24(1), 1-11.

Hasan, A. A. (2017). Work Stress, Coping Strategies and Levels of Depression among Nurses Working in Mental Health Hospital in Port-Said City. International Archives of Nursing and Health Care, 3(2), doi: 10.1080/17542863.2017.1343859.

Iversen, V. C., Aasen, O. H., Guzey, I. C., \& Helvik, A. (2016). Incidence of Violent Behavior Among Patient in Psychiatric Intensive Care Unit. European Journal of Psychiatric, 30(1), 67-78.

Konstantinos, N., \& Christina, O. (2008). Factors Influencing Stress and Job Satisfaction of Nurses Working in Psychiatric Unit: a Research Review. Health Science Journal, 2(4): 183-195.

Konzon, V., \& Zacharova, E. (2016). Stress Factor in the Work of Nurses. Clinical Social Work and Health Intervention, 7(2), 105-115.

Mohamedkheir, R. A., Amara, Z. M., Balla, S. A., \& Mohamed, H. A. (2016). Occupational Stress Among Nurses Working in Intensive Care Unit in Public Hospital of Khartoum State, Sudan 2016. American Journal of Health Research , 4(6): 166-171, Doi: 10.11648/j.ajhr.20160406.13 .

Moustaka, E., \& Constantinidis, C. T. (2010). Sources and Effect of Work-Related Stress in Nursing. Health Science Journal, 4(4), 210216.

Muatsiroh, A., \& Siswati. (2017). Hubungan Antara Kecerdasan Interpersonal dengan Stres Kerja Perawat Instalasi Rawat Inap di Rumah Sakit Jiwa Daerah Surakarta. Jurnal Empati, 6(1): 34-39. 
Irman Somantri: The Differences of Nurses Work Stress in The Intensive Care Unit

Mulyani, Y., M, E. R., \& Ulfah, L. (2017). Hubungan Mekanisme Koping dengan Stres Kerja Perawat IGD dan ICU di RSUD Ulin Banjarmasin. Al-Ulum: Jurnal Ilmu Sosial dan Humaniora, 3(2).

NAPICU. (2014). National Minimum Standars for Psychiatric Intensive Care in General Adult Services. Dipetik July 4, 2018, dari National Association of Psychiatric Intensive Care \& Low Secure Units: http:// napicu.org.uk/wp-content/uploads/2014/12/ NMS-2014-final.pdf.

Rahmawati, Y., \& Purwanti, O. S. (2008). Hubungan Komunikasi Perawat-Dokter dengan Stres Kerja Perawat di Instalasi Rawat Inap (IRNP) Penyakit Dalam Rumah Sakit Umum Daerah Sragen. Berita Ilmu Keperawatan, 1(3):107-112.

Ratnaningrum, C., \& putri, Y. S. (2012). Tingkat Stres Kerja Perawat di Ruang Psikiatri Intensif Rumah Sakit Dr. H. Marzoeki Mahdi Bogor.

Sari, R., Yusran, S., \& Ardiansyah, R. T. (2017). Faktor yang Berhubungan dengan Stres Kerja pada Perawat di Ruang Rawat Inap Rumah Sakit Jiwa Provinsi Sulawesi Tenggara 2016. Jurnal Ilmiah Mahasiswa Kesehatan Masyarakat, 2(6).

Sato, Y., Miyake, H., \& Theriault, G. (2009). Overtime work and Stress Response in a Group of Japanese Workers. Occupational Medicine, 1(1): 14-19, Doi:10.1093/occmed/ kqn141 .

Satrio, P. (2015). Pengaruh Shift Kerja dan Stres Kerja Terhadap Kinerja Pramuniaga di PT Circleka Indonesia Utama Cabang Yogyakarta. Skripsi: Universitas Negri Yogyakarta.

Senining, C. C., \& Gilchrist, K. (2012). Stress and Coping Mechanisms Used by Mental Health Nurses in Acute Psychiatric Settings.

Setiawan, S. N. (2015). Hubungan Perilaku agresif dengan Stres Perawat di Psikiatri Intensive Care Unit (PICU) RSJD Surakarta. Skripasi: STIKES Kusuma Husada Surakarta.
Shimazu, A., Nordin, R. B., Dollard, M., \& Oakman, J. (2016). Psychosocial Factors at Work in the Asia Pacific: From Theory to Practice. Switzerland: Springer.

Sitorus, E., \& Wulandari, S. (2015). Gambaran Tingkat Stres pada Perawat di Ruang Rawat Inap Lantai 5 Blok C Rumah Sakit Umum Daerah Kota Jakarta Utara. Jurnal Keperawatan Husada Karya Jaya, 1(2).

Sobekwa, Z. C., \& Arunachallam, S. (2015). Experiences of Nurse Caring for Mental Health Care Users in an Acute Admissions Unit at a Psychiatric Hospital in the Western Cape Province. 1-9, Doi:10.4102/curationis. v38i2.1509.

Sunyoto, D., \& Burhanudin. (2011). Perilaku Organisasional. Yogyakarta: CAPS.

Totman, J., Hundt, G. L., Wearn, E., Paul, M., \& Johnson, S. (2011). Factor Affecting Staff Morale on Inpatient Mental Health Wards in England: A Qualitative Investigation. BMC Psychiatry, 11(68), 1-10, doi: 10.1186/1471244X-11-68.

Ulfah, N. (2011). Tingkat Stres Kerja Pada Perawat di Unit Rawat Inap Rumah Sakit Jiwa Daerah Provinsi Sumatra Utara Tahun 2011. Skripsi: Universitas Sumatra Utara.

Utomo, D. P., \& Sulastri. (2009). Hubungan Stres Kerja dengan Adaptasi Perawat di Instalasi Gawat Darurat RSUD Pandan Arang Boyolali. 2(3).

Widoretno, A. W. (2018). Faktor yang Berhubungan dengan Stres Kerja Perawat di Instalasi Rawat Inap RSJ Dr. Radjiman Wediodiningrat Lawang. Skripsi: Universitas Airlangga.

Wijono, S. (2010). Psikologi Industri dan Organisasi: Dalam Suatu Bidang Gerak Psikologi Sumber Daya Manusia. Jakarta: Prenadamedia Group.

Yana, D. (2015). Stres Kerja pada Perawat Instalasi Gawat Darurat di RSUD Pasar Rebo Tahun 2014. Jurnal Administrasi Kebijakan Kesehatan, 1(2). 
Irman Somantri: The Differences of Nurses Work Stress in The Intensive Care Unit

Yoshizawa, K., Sugawara, N., Yasui-Furukori, N., Danjo, K., Furukori, H., Yasushi, S., et al. (2014). Relationship Between Occupational Stress and Depression among Psychiatric Nurses in Japan. Archives of Environmental and Occupational Health, 71(1), 10-15, doi: $10.1080 / 19338244.2014 .927345$.
Zaki, R. A. (2016). Job Stress and SelfEfficacy among Psychiatric Nursing Workingin Mental Health Hospital at Cairo, Egypt. Journal of Education and Practice, $7(20)$ 